\title{
Can Detection of Non-alcoholic Fatty Liver Disease be Coincidental in Young Patients with Chronic Hepatitis B?
}

\author{
Genç Kronik Hepatit B Hastalarında Alkolik Olmayan Yağı Karaciğer Hastalığı Saptanması \\ Rastlantisal Olabilir mi?
}

\author{
Zehra KARACAER1', Gökcan OKUR², Hakan ÇERMIK33, Özgür AVCI4 \\ 'Etimesgut Military Hospital, Department of Infectious Diseases and Clinical Microbiology, Ankara, Turkey \\ 2Etimesgut Military Hospital, Department of Radiology, Ankara, Turkey \\ ${ }^{3}$ Etimesgut Military Hospital, Department of Pathology, Ankara, Turkey \\ ${ }^{4}$ Etimesgut Military Hospital, Department of Biochemistry, Ankara, Turkey
}

\begin{abstract}
Objective: The objective of this study was to determine the factors associated with the presence of non-alcoholic fatty liver disease (NAFLD) in young persons who are hepatitis $B$ surface antigene (HBsAg)-positive and negative, and to investigate if NAFLD coexisting hepatitis B virus (HBV) is coincidental.

Materials and Methods: This retrospective study, conducted in a military hospital in Turkey, included a total of 384 subjects. The subjects were divided into two groups according to the presence of NAFLD detected by ultrasonography (US). Sociodemographic characteristics, biochemical, histopathological, virological and US results were recorded. Statistical analysis was performed using SPSS 22.0.

Results: The median age of the patients, all of whom were male, was 26 years (20-40). NAFLD was identified in $16.9 \%$ of patients. HBsAg positivity was found in $36.9 \%$ of patients with NAFLD. It was remarkable that no statistically significant difference was found in $\mathrm{HBsAg}$ positivity between the patients with and without NAFLD ( $p=0.661$ ). NAFLD was found in $13.2 \%$ of HBsAg-positive patients. NAFLD was determined in $20.3 \%$ of $\mathrm{HBsAg}$-negative patients. No significant difference was found in NAFLD grades between HBsAg-positive and negative patients ( $p=0.158$ ). In the present study, only $\mathrm{Y}$-glutamyl transferase in HBsAg positive patients, and age, alanine transaminase and aspartate transaminase in HBsAg negative patients were determined as the most important factors associated with the presence of NAFLD. Conclusion: We found that $\mathrm{HBsAg}$ positivity is not correlated with the development of NAFLD in young patients, and coexistence of NAFLD and HBV might be coincidental.
\end{abstract}

Keywords: Non-alcoholic fatty liver disease, chronic hepatitis B, ultrasonograpy
OZZ

Amaç: Bu araştırmanın amacı hepatit B yüzey antijeni (HBsAg) pozitif ve negatif genç hastalarda alkolik olmayan yağlı karaciğer hastalığının (AOYKH) sıklığııı, AOYKH oluşumu ile ilişkili faktörleri ve hepatit B virüsü (HBV) ile AOYKH'nin birlikte saptanmasının rastlantısal olup olmadığını ortaya koymaktı.

Gereç ve Yöntemler: Bu retrospektif çalışma bir askeri hastanede yapıldı. Çalışmaya toplam 384 hasta dahil edildi. Hastalar ultrasonografik (US) olarak saptanan AOYKH'na göre iki gruba ayrıldı. Grupların sosyodemografik, biyokimyasal, histopatolojik, virolojik ve US bulguları retrospektif olarak kaydedildi. SPSS 22,0 kullanılarak istatistiksel analizleri yapıldı.

Bulgular: Tümü erkek olan hastaların yaş ortancası 26 yı (20-40 yıl) saptandı. Hastaların \%16,9'unda AOYKH tanımlandı. AOYKH olan hastaların \%36,9'unda $\mathrm{HBsAg}$ pozitifliği saptandı. AOYKH olan ve olmayan hastalar arasında $\mathrm{HBsAg}$ pozitifliği açısından istatistiksel olarak önemli fark saptanmadı $(p=0,661)$. HBsAg pozitif hastaların $\% 13,2$ 'sinde, HBsAg negatif hastaların \%20,3'ünde $\mathrm{AOYKH}$ belirlendi. HBsAg pozitif ve negatif hastalar arasında $\mathrm{AOYKH}$ açııından önemli fark bulunmadı ( $p=0,158)$. HBsAg pozitif hastalarda $\gamma$-glutamil transferaz, HBsAg negatif hastalarda yaş, alanin transaminaz ve aspartat transaminaz AOYKH varlığı ile ilişkili en önemli faktörler olarak belirlendi.

Sonuç: Bu çalışmada HBsAg pozitifliğinin genç hastalarda AOYKH gelişimi ile ilişkili olmadığını, HBV ve AOYKH birlikteliğinin rastlantısal olabileceğini saptadık.

Anahtar Kelimeler: Alkolik olmayan yağlı karaciğer hastalığı, kronik hepatit $\mathrm{B}$, ultrasonografi

Karacaer Z, Okur G, Cermik H, Avcı Ö. Can Detection of Non-alcoholic Fatty Liver Disease be Coincidental in Young Patients with Chronic Hepatitis B?. Viral Hepat J 2016;22:43- 47 


\section{Introduction}

There are 400-500 million hepatitis B virus (HBV) carriers worldwide (1). Although the prevalence differs accross the various regions, $4 \%$ of the population in Turkey are carriers of HBV (2), with a rate of $2.8 \%$ in 20 year-old people (1).

Fatty liver disease may be observed as a comorbidity in patients with HBV infection. Hepatosteatosis, or fatty liver, is defined as an accumulation of triglycerides in the cytoplasm of hepatocytes. If hepatosteatosis occurs without heavy alcohol use, the term of non-alcoholic fatty liver disease (NAFLD) is used. NAFLD may be observed in the form of simple fat deposition as well as nonalcoholic steatohepatitis (NASH) with inflammation identified, and cirrhosis may develop (3).

The incidence of NAFLD and chronic hepatitis $\mathrm{B}(\mathrm{CHB})$ varies according to region. Various studies conducted in Brazil and in Taiwan have reported the incidence of NAFLD as $10-56 \%(4,5)$, while studies conducted in Turkey have reported the incidence as $39-42 \%(6,7)$. NAFLD does not contribute to the progression of HBV infection (8,9). Cindoruk et al. (10) showed that NAFLD had no negative effect on treatment success in patients with hepatitis B. It is difficult to establish a cause and effect relationship between HBV and NAFLD $(5,7)$. Does the relationship between HBV infection and NAFLD occur for the same reasons in other segments of society, and if so, is the association coincidental?

The objective of this study was to determine the factors associated with the presence of NAFLD in young persons who are hepatitis B surface antigene (HBsAg)-positive and negative, and to investigate if the coexistance of NAFLD and HBV is coincidental.

\section{Materials and Methods}

This retrospective study was conducted in a military hospital between January 1st, 2012 and June 30th, 2015. A total of 384 patients aged 20-40 years, who had undergone an abdominal ultrasonography (US) for any reason, were included in the study. Exclusion criteria were defined as positive serology for hepatitis $C$ virus, acute hepatitis findings, liver disease due to other reasons, and regular and heavy consumption of alcohol.

Patients' age, weight, height, alanine transaminase (ALT), aspartate transaminase (AST), $\gamma$-glutamyl transferase (GGT), alkaline phosphatase, fasting blood glucose (FBG) values, US, and HBsAg outcomes were obtained from the hospital data base. Body mass index (BMI) was calculated using height and weight (weight/height ${ }^{2}$ ). Hepatitis B e-antigene (HBeAg), HBV DNA values, histologic activity index (HAl) from liver biopsy outcomes, and fibrosis scores were recorded in 182 patients identified to be HBsAg-positive.

All patients were divided into two groups according to the presence of NAFLD which had been defined by US findings. Demographic and laboratory data were compared in order to evaluate their effect on development of NAFLD. In addition, all patients were further divided into two subgroups based on $\mathrm{HBsAg}$ positive and negative status, and NAFLD identified by US was investigated in these two groups. The subgroups were evaluated separately for the presence of NAFLD with demographic and laboratory data. Independent risk factors affecting the development of NAFLD were separately studied in all patients and the subgroups.
Hepatic US was performed with GE Logiq 5 PRO ultrasound system (GE Medical Systems - Milwaukee, WI, USA) using a convex broadband (4-10MhZ) transducer. NAFLD was graded by comparing diffusely increased echogenicity in the liver with echogenicity of the right kidney cortex. NAFLD grading was made according to the following criteria (11):

Grade 1: Diffuse increased echogenicity with normal vascular walls and normal diaphragm echogenicity.

Grade 2: Partially unclear echogenicity of intrahepatic artery/ vein walls and diaphragm.

Grade 3: Echogenicity of the diaphragm wall could not be observed and posterior segment of the liver was determined with difficulty.

Liver needle biopsy was performed with a 16-gauge Menghini needle under local anesthesia. Liver parenchyma was assessed using modified KNODELL scoring system (1995 ISHAK) (12).

The Helsinki Declaration and Good Clinical Practice Guidelines were followed in all the processes of patient inclusion, data collection and analysis, and reporting. The study was approved by the Local Ethics Committee.

\section{Statistical Analysis}

Statistical analysis was carried out utilizing SPSS IBM 22.0 software. Distribution of the data was studied with the KolmogorovSmirnov test. Descriptive statistics were performed for each group. Normally distributed continuous variables were expressed with mean + standard deviation, non-normally distributed data median (minimum-maximum), and categorical data with number and percentage. Differences between the groups were analyzed using the student's t-test and the Mann-Whitney $U$ test. Categorical variables were studied using the Pearson $X^{2}$ and Fisher's Exact tests. Independent risk factors for the development of NAFLD were determined by logistic regression analysis. A p value of less than 0.05 was considered statistically significant.

\section{Results}

The study included a total of 384 patients. The median age of the patients, all of whom were male, was 26 years (20-40). NAFLD was identified in 65 (16.9\%) patients. Of these 65, NAFLD was defined as grade 1 in $44(67.7 \%)$ and grade 2 in 20 (30.8\%) patients, while one patient $(1.5 \%)$ had grade 3 NAFLD. Demographics and laboratory values of the groups according to the presence of NAFLD are summarized in Table 1. Age, weight, BMI, and GGT values were found to be higher in patients with NAFLD compared to those without NAFLD (for each, $\mathrm{p}<0.001$ ). Although the other laboratory parameters were higher in patients with NAFLD defined, the differences did not reach statistical significance (Table 1). HBsAg positivity was found in $36.9 \%$ of patients with NAFLD. It was remarkable that no statistically significant difference was found in HBsAg positivity between patients with and without NAFLD $(p=0.661$ ) (Table 1).

HBsAg positivity was identified in 182 (47.4\%) of patients included in the study. The median HAl value of the patients was 5 (minimum-maximum: 0-14) and the median fibrosis score was 2 (minimum-maximum: 0-5). HBeAg positivity was observed in around $50 \%$. NAFLD was found in $13.2 \%$ of HBsAg-positive 
patients. There were significant differences in terms of weight $(p=0.018)$, BMI $(p=0.001)$, and GGT $(p=0.002)$ according to the presence of NAFLD among the patients in this group. NAFLD was found in $20.3 \%$ of HBsAg-negative patients. In this group of patients, significant differences were found in terms of age $(p=0.002)$, weight $(p<0.001)$, BMI $(p<0.001)$, ALT $(p<0.001)$, AST $(p<0.001)$, GGT $(p<0.001)$, and FBG levels $(p<0.001)$. Demographics and laboratory data of $\mathrm{HBsAg}$-negative and -positive patients according to the presence of NAFLD are given in Table 2.

Among the HBsAg-positive patients, 18 patients (75\%) were found to have NAFLD grade 1, 5 patients $(20.8 \%)$ had grade 2 , and NAFLD grade 3 was defined in 1 patient (4.2\%). In HBsAg-negative patients, NAFLD was determined as grade 1 in 26 patients (63.4\%) and grade 2 in 15 patients (36.6\%), while none of these patients had grade 3 NAFLD. No significant difference was found in NAFLD grades between HBsAg -positive and -negative patients ( $p=0.158$ ).

In the present study, only GGT in HBsAg-positive patients, and age, ALT, and AST in HBsAg-negative patients were determined as the most important factors associated with the presence of NAFLD. GGT level was found to be determining factor associated with the presence of NAFLD in HBsAg-positive patients. It is noteworthy that AST level negatively affected occurrence of NAFLD, and in patients HBsAg-negative patients, the probability of having NAFLD decreased as the level of AST increased. We found that age and ALT levels increased the odds of determination of NAFLD, and in HBsAg-negative patients, the most important factor was ALT (Table 3).

\section{Discussion}

In this study, NAFLD was found in $16.9 \%$ of all patients. We observed that NAFLD was more infrequent in CHB patients, and that HBsAg was not a significant factor in patients with NAFLD. The prevalence of NAFLD is $19.8 \%$ in our country (13), whereas in Western populations this rate has been reported to be between $20 \%$ and $30 \%$ (14). According to the Turkish data, NAFLD is found in $21.1-52 \%$ of inactive HBsAg carriers $(6,15,16)$, and in $39 \%$ of CHB patients (7). In their study performed in Indonesia, Lesmana et al. (8) found the incidence of NAFLD to be $29.9 \%$. Poortahmasebi et al. (17) in their study performed in Iranian patients reported that $44.4 \%$ of CHB patients had NAFLD. Similar to our study, Wang et al. (5) also reported that the incidence of NAFLD in HBsAgpositive patients was similar to that in HBsAg-negative patients. In addition, it has been reported in a meta-analysis examining fatty liver in HBV patients that the incidence of NAFLD among HBV patients was similar to that of the general population (18). It is noteworthy that the incidence of NAFLD in our study was lower compared to the data from our country and other countries, and that HBsAg positivity did not increase the incidence of NAFLD. This result suggests that NAFLD identified in CHB patients might be coincidental.

In the present study, NAFLD grade was found to be lower in HBsAg-positive patients than in HBsAg-negative subjects. In their study, Uyanıkoğlu et al. (6) found that $73 \%$ of HBV-infected patients had grade 1,21\% had grade 2, and 6\% had grade 3 fatty liver. In their study, Korkmaz et al. (16) found that $61 \%$ of inactive hepatitis B carriers had grade $1,35 \%$ had grade 2 , and $4 \%$ had grade 3 fatty liver. It has been noticed in previous studies that low grade fatty liver is common among HBV patients. Similarly, low grades of NAFLD found in our study suggest that the progression of fattening level might be reduced in young people by several regulations, such as lifestyle changes and diet. Furthermore, in our study, there was no correlation established between HBsAg positivity and NAFLD grade, supporting that this association is coincidental.

It has been demonstrated in several studies that NAFLD is more common in men and in advanced age groups $(13,19)$. In the present study, HBsAg-negative patients were in a young age group, and the incidence of NAFLD was significantly higher in older patients in the same group. Previous studies have reported that male gender and advanced age are significant factors in HBV patients $(6,7,15,16,17)$. However, in our study, we could not find a similar correlation with age in patients with positive HBsAg.

There were also obese patients in our study. It is known that the prevalence of NASH which is the advanced stage of NAFLD, is six times higher in obese patients compared to persons within

\begin{tabular}{|c|c|c|c|c|}
\hline Variable & All patients $(n=384)$ & NAFLD positive $(n=65,16.9 \%)$ & NAFLD negative $(\mathrm{n}=319,83.1 \%)$ & $p$ value \\
\hline Age (year) & $26(20-40)$ & $31(20-40)$ & $25(20-40)$ & $<0.001 \pm$ \\
\hline Height $(\mathrm{cm})$ & $1.77(1.59-1.94)$ & $1.78(1,62-1.94)$ & $1.77(1.59-1.93)$ & 0.997 \\
\hline Weight (kg) & $76.5(50-115)$ & $80(60-103)$ & $75(50-115)$ & $<0.001^{ \pm}$ \\
\hline BMI $\left(\mathrm{kg} / \mathrm{m}^{2}\right)$ & $24.7(17.4-35.5)$ & $26(19.6-34.6)$ & $24(17.3-35.5)$ & $<0.001^{ \pm}$ \\
\hline ALT $(0-45 \mathrm{U} / \mathrm{L})^{*}$ & $51(11-553)$ & $55(15-207)$ & $50(11-553)$ & 0.095 \\
\hline AST $(0-35 \mathrm{U} / \mathrm{L}) *$ & $31.5(15-188)$ & $32(16-75)$ & $31(15-188)$ & 0.494 \\
\hline GGT $(0-55 \mathrm{U} / \mathrm{L})^{*}$ & $24(7-114)$ & $29(13-112)$ & $23(7-114)$ & $<0.001^{ \pm}$ \\
\hline $\operatorname{ALP}(38-155 \mathrm{U} / \mathrm{L})^{*}$ & $72(38-236)$ & $72(45-150)$ & $72(38-236)$ & 0.903 \\
\hline FBG $(74-106 \mathrm{mg} / \mathrm{dL}) *$ mean $+\mathrm{SD}$ & $93.17 \pm 8.86$ & $94.69 \pm 9.74$ & $92.86 \pm 8.65$ & 0.162 \\
\hline \multicolumn{5}{|l|}{ HBsAg $(n / \%)$} \\
\hline Positive & $182(47.4)$ & $24(36.9)$ & $158(49.5)$ & 0.661 \\
\hline Negative & $202(52.6)$ & $41(63.1)$ & $161(50.5)$ & \\
\hline
\end{tabular}


a normal weight range (19). Numerous studies have shown that $\mathrm{BMI}$ is an important factor associated with NAFLD in patients with hepatitis $B$ and in other segments of society without HBV infection $(4,7,8,9,10,13,17,20)$. Likewise, in our study, we found that weight gain, and thus BMI, is crucial in terms of the presence of NAFLD and makes a significant difference in NAFLD development.

In the present study, GGT was significantly high both in HBsAgpositive and -negative patients detected to have NAFLD. The importance of GGT levels in patients with hepatitis B differs among the studies. Korkmaz et al. (16) mentioned that GGT is important for NAFLD, while Altıparmak et al. (7) and Nau et al. (20) found no significant difference in terms of GGT levels.

In a study by Wang et al. (5) with HBsAg positive and negative patient groups, risk factors contributing to NAFLD were triglycerides, BMI, and insulin resistance. In our study, the only determinative factor for CHB patients was GGT. In these patients, the control for abdominal US would be reasonable for NAFLD in the case of high GGT levels. Among patients with negative HBsAg, those with high ALT levels and advanced age may require evaluation for NAFLD.

The number of studies comparing the incidence of NAFLD in CHB patients and those with negative HBsAg is limited (5). Furthermore, no study was found in the literature screening that investigates this comparison in between $20-40$ years old patients. We believe that our results will make a contribution to the literature because of the young patient population we studied, and the comparison of our data between HBsAg positive and negative groups. We selected histopathologically-proven $\mathrm{CHB}$ patients in order to investigate the presence of additional disease which might contribute to the existing damage at certain levels in the liver tissue. This feature distinguishes our study from the other studies. However, our study has some limitations. We had difficulty in finding similar studies with which we could compare our data. Our patient population consisted solely of male patients because of military hospital. Lack of data for both

\begin{tabular}{|c|c|c|c|c|c|c|}
\hline \multirow[t]{2}{*}{ Variable } & \multicolumn{3}{|c|}{ HBsAg positive patients ( $\mathrm{n}=182$ ) } & \multicolumn{3}{|c|}{ HBsAg negative patients $(n=202)$} \\
\hline & $\begin{array}{l}\text { NAFLD positive } \\
(\mathrm{n}=24,13.2 \%)\end{array}$ & $\begin{array}{l}\text { NAFLD negative } \\
(n=158,86.8 \%)\end{array}$ & $p$ value & $\begin{array}{l}\text { NAFLD positive } \\
(n=41,20.3 \%)\end{array}$ & $\begin{array}{l}\text { NAFLD negative } \\
(\mathrm{n}=161,79.7 \%)\end{array}$ & $p$ value \\
\hline Age (year) & $21(20-40)$ & $21(20-33)$ & 0.078 & $35(23-40)$ & $30(22-40)$ & $0.002 \pm$ \\
\hline Height $(\mathrm{cm})$ & $1.74(1.62-1.94)$ & $1.75(1.59-1.90)$ & 0.109 & $1.79(1.67-1.88)$ & $1.78(1.65-1.93)$ & 0.348 \\
\hline Weight (kg) & $80(60-103)$ & $73(50-115)$ & $0.018^{ \pm}$ & $81(67-93)$ & $77(60-97)$ & $<0.001 \pm$ \\
\hline BMI $\left(\mathrm{kg} / \mathrm{m}^{2}\right)$ mean + SD & $26.3 \pm 3.11$ & $23.9 \pm 3.38$ & $0.001 \pm$ & $25.5 \pm 1,64$ & $24.3 \pm 1.68$ & $<0.001 \pm$ \\
\hline $\operatorname{ALT}(0-45 \mathrm{U} / \mathrm{L}) *$ & $86(47-207)$ & $81(43-553)$ & 0.927 & $44(15-125)$ & $24(11-107)$ & $<0.001^{ \pm}$ \\
\hline AST $(0-35 \mathrm{U} / \mathrm{L}) *$ & $43.5(30-75)$ & $43(24-188)$ & 0.538 & $28(16-65)$ & $23(15-63)$ & $<0.001 \pm$ \\
\hline GGT $(0-55 \mathrm{U} / \mathrm{L})^{*}$ & $39(20-112)$ & $26.5(8-79)$ & $0.002 \pm$ & $28(13-74)$ & $20(7-114)$ & $<0.001^{ \pm}$ \\
\hline $\operatorname{ALP}(38-155 \mathrm{U} / \mathrm{L}) *$ & $81(47-150)$ & $80(40-236)$ & 0.944 & $67(45-131)$ & $65(38-159)$ & 0.422 \\
\hline FBG $(74-106 \mathrm{mg} / \mathrm{dL}) *$ mean $+\mathrm{SD}$ & $88.21 \pm 9.02$ & $91.79 \pm 10.09$ & 0.102 & $98.49 \pm 8.06$ & $93.90 \pm 6.84$ & $0.001^{ \pm}$ \\
\hline
\end{tabular}

Table 3. The factors associated with the presence of non-alcoholic fatty liver disease

\begin{tabular}{|c|c|c|c|c|c|}
\hline & B & Wald & $p$ value & OR & Cl \\
\hline GGT (U/L) & 0.040 & 7.719 & 0.005 & 1.041 & $1.012-1.071$ \\
\hline Cox and snell R2 & 0.103 & & & & \\
\hline Nagelkerke R2 & 0.190 & & & & \\
\hline \multicolumn{6}{|l|}{ HBsAg negative patients } \\
\hline Age (year) & 0.154 & 9.819 & 0.002 & 1.166 & $1.059-1.284$ \\
\hline ALT (U/L) & 0.101 & 16.65 & $<0.001$ & 1.106 & $1.054-1.161$ \\
\hline AST (U/L) & -0.125 & 5.702 & 0.017 & 0.882 & $0.796-0.978$ \\
\hline Constant & -18.264 & 14.481 & $<0.001$ & $<0.001$ & \\
\hline
\end{tabular}


genders created a limiting condition for our study. Since we did not include patients receiving treatment and inactive HBsAg carriers, we could not make any interpretation about these groups.

\section{Conclusion}

Our study found that HBsAg positivity is not correlated with the development of NAFLD in young patients, and coexistence of NAFLD with HBV might be coincidental. Weight gain might be the cause for the development of NAFLD in patients with HBV. In addition, we found predictive factors for the presence of NAFLD to be high GGT levels in HBsAg-positive patients, and age, high ALT, and high AST levels in HBsAg-negative patients. However, these results should be confirmed with additional, larger studies that include both genders.

\section{Ethics}

Ethics Committee Approval: The Helsinki Declaration and Good Clinical Practice Guidelines were followed in all the processes of patient inclusion, data collection and analysis, and reporting. The study was approved by the Local Ethics Committee, Informed Consent: It was taken.

Peer review: External and Internal peer-reviewed.

\section{Authorship Contributions}

Concept: Zehra Karacaer, Gökcan Okur, Design: Zehra Karacaer, Gökcan Okur, Data Collection or Processing: Zehra Karacaer Gökcan Okur, Hakan Çermik, Özgür Avcl, Analysis or Interpretation: Zehra Karacaer, Gökcan Okur, Literature Search: Zehra Karacaer, Gökcan Okur, Writing: Zehra Karacaer, Gökcan Okur, Hakan Çermik, Özgür Avcl.

Conflict of Interest: No conflict of interest was declared by the authors.

Financial Disclosure: The authors declared that this study received no financial support.

\section{References}

1. Altay T, Uskun E, Akcam FZ. Seroprevalence of hepatitis B surface antigen and its correlation with risk factors among new recruits in Turkey. Braz J Infect Dis 2012;16:339-344.

2. Türk Karaciğer Araştırmaları Derneği Ulusal Hepatit Sıklığ Çalışması (TURKHEP2010), www.tasl.org.tr/dosya/tasl_Ulusal_ Hepatit_sikligi_Calismasi.pdf.

3. Obika M, Noguchi H. Diagnosis and evaluation of nonalcoholic fatty liver disease. Exp Diabetes Res 2012;2012:145754.

4. Nascimento AC, Maia DR, Neto SM, Lima EM, Twycross M, Baquette RF, Lobato CM. Nonalcoholic Fatty liver disease in chronic hepatitis $\mathrm{B}$ and $\mathrm{C}$ patients from Western Amazon. Int J Hepatol 2012;2012:695950.
5. Wang CC, Hsu CS, Liu CJ, Kao JH, Chen DS. Association of chronic hepatitis $B$ virus infection with insulin resistance and hepatic steatosis. J Gastroenterol Hepatol 2008;23:779-782.

6. Uyanıkoğlu A, Coşkun M, Binici DN, Öztürk Y. The frequency of hepatosteatosis in inactive hepatitis B carries. Viral Hepatitis Journal 2011;17:62-65

7. Altıparmak E, Koklu S, Yalinkilic M, Yuksel O, Cicek B, Kayacetin $\mathrm{E}$, Sahin T. Viral and host causes of fatty liver in chronic hepatitis B. World J Gastroenterol 2005;28;11:3056-3059.

8. Lesmana LA, Lesmana CR, Pakasi LS, Krisnuhoni E. Prevalence of hepatic steatosis in chronic hepatitis $B$ patients and its association with disease severity. Acta Med Indones 2012;44:35-39

9. Peng $D$, Han $Y$, Ding $H$, Wei $L$. Hepatic steatosis in chronic hepatitis B patients is associated with metabolic factors more than viral factors. J Gastroenterol Hepatol 2008;23:1082-1088.

10. Cindoruk M, Karakan T, Unal S. Hepatic steatosis has no impact on the outcome of treatment in patients with chronic hepatitis B infection. J Clin Gastroenterol 2007;41:513-517.

11. Incedayı M, Pekkafali MZ, Sildiroglu HO, Basekim CC, Kizilkaya E. Sonographic and histopathological correlation in diffused fatty liver. Anatol J Clin Investig 2012;6:1-5.

12. Ishak KG, Zimmerman HJ. Morphologic spectrum of druginduced hepatic disease. Gastroenterol Clin North Am 1995;24:759-786.

13. Celebi $S$, Ataseven $H$, Mengucuk $E$, Deveci SH, Acık $Y$, Bahcecioglu IH. Epidemic features of nonalcoholic fatty liver in urban community of Elazıg. Akademik Gastroenteroloji Dergisi 2006;5:41-46

14. Bellentani S, Scaglioni F, Marino M, Bedogni G. Epidemiology of non-alcoholic fatty liver disease. Dig Dis 2010;28:155-161.

15. Inci A, Meral CE. Ultrasonographic Assessment of the Prevalence of Hepatic Steatosis in Inactive Hepatitis B Carriers. Viral Hepat J 2013;19:46-48.

16. Korkmaz P, Aykın N, Cevik FC, Alpay $Y, N a z ~ H$, Gulduren HM, Hepatic Steatosis in Inactive Hepatitis B Carriers: Prevalence, Evaluation of Viral and Biochemical Parameters. Viral Hepat $\mathrm{J}$ 2013;19:144-147.

17. Poortahmasebi V, Alavian SM, Keyvani H, Norouzi M, Mahmoodi M, Jazayeri SM. Hepatic steatosis: prevalence and host/viral risk factors in Iranian patients with chronic hepatitis B infection. Asian Pac J Cancer Prev 2014;15:3879-3884.

18. Machado MV, Oliveira AG, Cortez-Pinto $H$. Hepatic steatosis in hepatitis $B$ virus infected patients: meta-analysis of risk factors and comparison with hepatitis $C$ infected patients. J Gastroenterol Hepatol 2011;26:1361-1367.

19. Kara M, Erdal M. A Public Health Issue that Increased Prevelance: Non-Acholic Fatty Liver Disease. TAF Prev Med Bull 2014;13:65-76.

20. Nau AL, Soares JC, Shiozawa MB, Dantas-Corrêa EB, Schiavon Lde L, Narciso-Schiavon JL. Clinical and laboratory characteristics associated with dyslipidemia and liver steatosis in chronic HBV carriers. Rev Soc Bras Med Trop 2014;47:158-164. 